\title{
PENINGKATAN KAPASITAS DAYA LISTRIK PADA PEMBANGKIT LISTRIK TENAGA MIKRO HIDRO BINTANG ASIH GUNA MEMENUHI KEBUTUHAN PENERANGAN
}

\author{
Rimbawati $^{1 *}$, Abdul Azis Hutasuhut ${ }^{1}$, Muharnif ${ }^{2}$ \\ ${ }^{1}$ Jurusan Teknik Elektro, Universitas Muhammadiyah Sumatera Utara, Medan, Indonesia \\ ${ }^{2}$ Jurusan Teknik Mesin, Universitas Muhammadiyah Sumatera Utara, Medan, Indonesia \\ *Penulis Korespodensi: rimbawati@umsu.ac.id
}

\begin{abstract}
Abstrak
Bintang Asih merupakan salah satu dusun terpencil di Desa Rumah Sumbul Kecamatan STM Hulu Kabupaten Deli Serdang dengan jumlah penduduk 140 jiwa dalam 25 Kepala Keluarga (KK) dan tergolong wilayah desa tertinggal dengan fasilitas penerangan menggunakan Pembangkit Listrik Tenaga Mikro Hidro (PLTMH) berkapasitas 1,1 KW. Pembangkit dan sistem distribusi di desain sangat sederhana sehingga tidak memenuhi Standart Umum Instalasi Listrik (PUIL. Selanjutnya Kapasitas pembangkit tersebut tidak mencukupi untuk memenuhi kebutuhn warga sebanyak $25 \mathrm{KK}$ yang ada di dusun tersebut. Berdasarkan hal ini maka pengabdian masyarakat ini akan melakukan peningkatan kapasitas PLTMH tersebut menjadi $5 \mathrm{~kW}$ dengan mengubah kincir menjadi turbin serta melakukan substitusi IPTEK berupa pelatihan manajemen pengelolaan pembangkit dan peberdayaan ekonomi melalui industri gula merah. Pada akhir program pengabdian ini disimpulkan bahwa telah dilakukan peningkatan kapasitas PLTMH sebesar $5 \mathrm{KW}$ dengan meng-upgrade kincir air menjadi turbin, melakukan perubahan sistem distribusi sesuai PUIL. melakukan pemasangan Electronic Load Control (ELC) pada pembangkit, Mini Circuit Breaker (MCB), saklar dan stop kontak di setiap rumah warga serta melakukan sosialisasi manajemen pemeliharaan PLTMH. Saat ini warga sudah menikmati fasilitas penerangan yang lebih memadai dengan perolehan daya $200 \mathrm{Watt} / \mathrm{KK}$. Dari sisi peningkatan ekonomi telah tumbuh home industry gula aren dengan total produksi $60 \mathrm{~kg} / \mathrm{minggu}$.
\end{abstract}

Kata Kunci: PLTMH Bintang Asih, PUIL, ELC.

\begin{abstract}
Bintang Asih is one of the remote hamlets in Rumah Sumbul Village, STM Hulu Subdistrict, Deli Serdang Regency with a population of 140 people in 25 families and classified as underdeveloped rural areas with lighting facilities using $1.1 \mathrm{KW}$ capacity Micro Hydro Power Plant (MHP). The generator and distribution system are designed so simple that they do not meet the General Standards for electrical Installation Furthermore, the capacity of the plant is insufficient to meet the needs of as many as 25 households in the hamlet. Based on this problems, community service will increase the capacity of the MHP to $5 \mathrm{~kW}$ by turning the windmill into a turbine and substituting science and technology in the form of training in power management and economic empowerment through the brown sugar industry, and at the end of this service program it was concluded that the capacity of $5 \mathrm{KW}$ of PLTMH had been upgraded by upgrading changes to the distribution system according to General Standards for electrical Installation, installs Electronic Load Control (ELC) on power plants, Mini Circuit Breakers (MCB), switches and sockets in every house and disseminates MHP maintenance management. more adequate lighting with $200 \mathrm{Watt} / K K$ power gain. In terms of economic improvement, palm sugar industry has grown with a total production of $90 \mathrm{~kg} /$ week.
\end{abstract}

Keywords: Bintang Asih MHP, MCB, ELC.

\section{PENDAHULUAN}

Wilayah Kabupaten Deli Serdang membentang dari pesisir pantai selat malaka sampai pengunungan bukit barisan dengan ketinggian $0-500 \mathrm{~m}$ diatas permukaan laut. Topografi yang cukup ekstrim mengakibatkan sebaran penduduk tidak merata di seluruh wilayah. Tidak dapat dipungkiri walaupun Deli Serdang merupakan salah satu Kabupaten terdekat dengan Ibu
Kota Provinsi Sumatera Utara, namun masih cukup banyak wilayah yang tergolong desa tertinggal. Hal ini disebabkan medan yang cukup sulit untuk dijangkau, karena berada di pesisir pantai maupun diperbukitan atau karena wilayah tersebut tidak memiliki potensi yang memadai. 
Dusun Bintang Asih merupakan salah satu dusun terpencil di Desa Rumah Sumbul Kecamatan Sinembah Tanjung Muda (STM) Hulu Kabupaten Deli Serdang dengan jumlah penduduk 140 jiwa dalam 25 Kepala Keluarga (KK) yang tergolong desa tertinggal. Mayoritas masyarakat di dusun ini berkerja sebagai buruh tani di perkebunan sawit, salak dan karet. Aktifitas lain masyarakat adalah penyadap aren untuk di jadikan gula merah, berladang padi, jagung, labu siam juga ubi. Ketertinggalan masyarakat Bintang Asih selama ini disebabkan akses jalan menuju wilayah tersebut cukup sulit untuk di jangkau, bahkan jika musim penghujan tiba warga harus berjalan kaki sejauh $4 \mathrm{~km}$ untuk membeli kebutuhan hidup di Ibu Kota Kecamatan yang berjarak $\pm 6 \mathrm{~km}$ dari Kantor Desa Rumah Sumbul.

Tidak berakhir sampai di situ, Dusun Bintang Asih yang berada pada ketinggian $380 \mathrm{~m}$ dpl juga harus menerima kenyataan pahit akan sulitnya air bersih. Setiap warga harus mengangkat air sejauh 1,5 km dari embung yang terletak di hulu sungai Sumbul untuk kebutuhan hidup sehari-hari. Sedangkan untuk aktifitas mandi dan cuci dilakukan warga di sungai tersebut. Kesulitan ekonomi membuat warga hanya mampu berpasrah dengan keadaan, sembari menanti uluran tangan pemerintah untuk memberikan solusi atas kesulitan yang mereka hadapi.

Pada tahun 2010, Pemerintah Daerah Kabupaten Deli Serdang mewujudkan impian warga dengan membangun Pembangkit Listrik Mikro Hidro (PLTMH) berkapasitas 3 KW melalui Proyek PNPM Mandiri Pedesaan. Masyarakat sangat antusias menerima kehadiran teknologi ini, walau mereka tidak memiliki pengetahuan tentang sistem dan perawatan sebuah PLTMH dan tidak memahami standarisasi instalasinya.

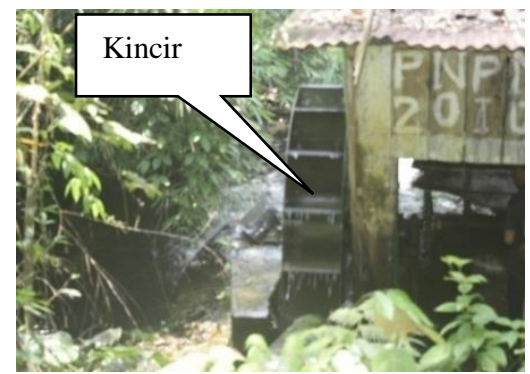

Gambar 1. Power House PLTMH Bintang.

Dalam pantauan lapangan ditemukan bahwa instalasi PLTMH sampai ke rumah warga tidak memenuhi Standar Ketenagalistrikan, seperti: setiap rumah tidak diberi pengaman/pembatas arus Mini Circuit Breker (MCB), setiap rumah tidak memiliki saklar sehingga semua lampu akan menyala siang dan malam selama pembangkit beroperasi, penempatan Automatic Voltage Regulator (AVR) di kandang bebek dan transmisi yang terpasang tidak sesuai dengan Peraturan Umum Instalasi Listrik (PUIL).

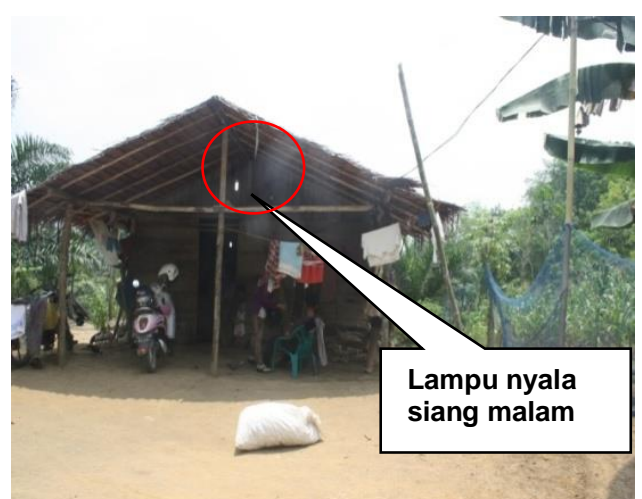

Gambar 2. Lampu warga tanpa saklar.

Seiring berjalannya waktu PLTMH Bintang Asih sudah berusia 6 tahun, perdebatan demi perdebatan pun mulai timbul akibat tidak adanya manajemen yang baik dalam pengelolaannya. Sehingga pada saat terjadi kerusakan warga tidak memiliki biaya untuk melakukan perbaikan. Berdasarkan keterangan Kepala Dusun, sudah 3 kali pembangkit mengalami kerusakan dan membutuhkan waktu yang cukup lama untuk dapat memperbaiki dan mengoperasikannya kembali. Kondisi ini membuat warga harus kembali menggunakan minyak tanah yang harganya $\mathrm{Rp}$ 11.000/ltr di wilayah tersebut. Tentunya kondisi ini semakin menambah keterpurukan ekonomi warga setempat.

Sebuah kajian literatur menyebutkan bahwa salah satu alternatif untuk memenuhi kebutuhan daya listrik bagi masyarakat terpencil adalah dengan membangun pusat-pusat pembangkit kecil (Microgenerator) di sekitar desa yang berdekatan dengan sumber saluran irigasi maupun aliran sungai-sungai yang berada didataran tinggi. Selanjutnya dilakukan eksperimen dengan mengaplikasikan Pembangkit Listrik Tenaga MikroHidro (PLTM) daya rendah (low power) $<3 \mathrm{Kw}$ dengan memanfaatkan motor induksi satu phasa sebagai generator induksi (Ion dkk, 2006).

Eksperimen tersebut dilanjutkan denagn memodifikasi motor induksi 3 phasa menjadi generator dapat dilakukan dengan mengubah desain rotor dan untuk mengurangi kecepatan nominal generator maka jumlah kutup pada rotor generator di perbanyak sehingga dapat mengurangi rugi-rugi transmisi pada perlengkapan Power House. Setelah melakukan pengujian terhadap hydroelctric generator 3 phasa diperoleh frekuensi keluaran sistem $49 \mathrm{~Hz}$, pada putaran 500 RPM dengan tegangan Phasa- Netral sebesar 183,85 Volt dan tegangan Phasa-Phasa sebesar 320,48 Volt (Rimbawati dkk, 2015).

Dengan merujuk pada eksperimen-eksperimen sebelumnya maka permasalahan masyarakat Bintang Asih dapat diselesaikan dengan melakukan peningklatan kapasitas PLTMH yang sudah ada agar dihasilkan daya yang lebih besar.

Berkaitan dengan hal tersebut diatas dari hasil diskusi yang dilakukan Tim PPDM UMSU dengan aparatur 
desa dan warga, memutuskan bahwa tujuan dari program pengabdian masyarakat ini adalah melakukan peningkatan kapasitas PLTMH Bintang Asih dari 1,1 KW menjadi $5 \mathrm{KW}$ serta melakukan pemasangan komponen transmisi dan distribusi ke rumah warga sesuai standar PUIL. Kemudian akan melakukan pelatihan menajemen operasional PLTMH agar warga mampu mengelola secara mandiri jika program sudah berakhir. Sedangkan dari sisi pemberdayaan masyarakat akan melakukan pendampingan pembuatan gula merah berbahan dasar nira aren.

\section{BAHAN DAN METODE \\ 2.1 Lokasi Kegiatan}

Program Pengembangan Desa Mitra (PPDM) ini akan dilaksanakan di Dusun Bintang Asih, Desa Rumah Sumbul Kecamatan STM Hulu Kabupaten Deli Serdang. Dalam melakukan kegiatan akan bekerjasama dengan Koperasi Serba Usaha Sumbul Mandiri, Serikat Tolong Menolong (STM) Al-Ikhlas serta KarangTaruna Remaja Muda Mandiri.

\subsection{Rencana Kegiatan}

Pembangunan PLTMH dengan pendekatan pemberdayaan masyarakat sangat relevan dengan kebijakan desentralisasi penyediaan energi (listrik) perdesaan. Pendekatan ini menyadari pentingnya kapasitas masyarakat untuk meningkatkan kemandirian dan kekuatan internal atas sumber daya material dan non material yang penting. Masyarakat memiliki potensi baik dilihat dari sumber daya alam maupun dari sumber sosial dan budayanya. Social preparation dalam pengembangan program listrik perdesaan perlu dilaksanakan mengingat masyarakat memiliki 'kekuatan' yang bila digali dan dikembangkan akan dapat menjadi kekuatan yang besar untuk pengentasan kemiskinan.

Berdasarkan hasil diskusi yang dilakukan oleh Tim PPDM, dengan mempertimbangkan potensi sumber daya alam, sosial ekonomi, kesehatan dan kesejahteraan masyarakat Dusun Bintang Asih, kegiatan ini akan melakukan: sosialisasi pembangunan PLTMH kepada masyarakat, survei potensi sumber daya air, perancangan sistem elektrikal dan mekanikal serta perbaikan instalasi listrik diselurh rumah warga.

\section{a. Sosialisasi Pembangunan PLTMH Kepada Masyarakat}

Pada tahap ini Tim PPDM melakukan sosialisasi terlebih dahulu kepada seluruh warga dusun Bintang Asih guna memberikan pemahaman berkaitan dengan projek yang akan dilaksanakan. Di samping itu juga menanamkan rasa memiliki terhadap program sehingga saat pelaksanaan nantinya warga akan sepenuh hati bergotong royong membantu Tim PPDM tanpa saling iri hati antara yang satu dengan yang lainnya.

\section{b. Survei Potensi Sumber Daya Air}

Pembangkit Listrik Tenaga Mikro Hidro (PLTMH) pada dasarnya sebuah pembangkit Listrik Tenaga Air (PLTA) dimana memerlukan dua data yang penting yaitu debit air dan ketinggian jatuh (Head) untuk menghasilkan tenaga yang bermanfaat. Ini adalah sebuah sistem konversi tenaga, menyerap tenaga dari bentuk ketinggian dan aliran, dan menyalurkan tenaga dalam bentuk daya mekanik ke daya listrik.

\section{c. Perancangan Sistem Elektrikal - Mekanikal}

Perangkat elektro-mekanik sistem PLTMH merupakan produk rekayasa dalam negeri. Komponen utama perlengkapan ini terdiri dari: turbin, sistem transmisi mekanik, generator sinkron, sistem Kontrol beban ELC (Electronic Load Control) dan Ballast load air heater. Selanjutnya adalah pemilihan jenis turbin yang akan di gunakan berdasarkan pada debit rencana, tinggi hidrolik netto dan jumlah unit yang dipasang.

Kemudian melakukan perancangan generator dengan putaran rendah $\leq 1000 \mathrm{rpm}$. Putaran yang lebih rendah akan meringankan pemilihan transmisi kecepatan yang diperlukan. Kapasitas generator sama atau lebih besar dari pada kapasitas yang bisa yang bisa dibangkitkan turbin. Pemilihan jenis generator yang akan digunakan juga didasarkan pada karakteristik sebagai berikut

- Tegangan kerja generator

- Kapasitas pembangkit

- Kesederhanaan konstruksi

- Generetor dengan standar produksi.

Untuk menjadikan mesin asinkron/induksi bekerja sebagai generator pembangkit listrik haruslah dipenuhi beberapa persyaratan sebagai berikut:

- Mesin harus diputar dengan putaran kira-kira, 1,03 $\mathrm{x}$ Ns.

- Mesin harus mendapat pasok arus induktif untuk membangkitkan tegangan eksitasi.

- Arus tersebut sapat dipasok oleh suatu kapisator atau dapat juga dipararel dengan jaringan.

\subsection{Pelaksanaan Program Pengembangan Desa Mitra}

Desain Pengabdian ini dilakukan sedemikian rupa sehingga langkah pengambilan data lapangan ini berupa pengambilan data potensi sumber daya air dengan ditinjau dari konstruksi sipil aliran air demografi dan kewilayahan serta sosio ekonomi dan kedua adalah Pengambilan data besaran listrik.

\section{a. Pengambilan data potensi sumber daya air}

Hal - hal yang dilakukan dalam pengambilan data potensi sumber daya air adalah sebagai berikut:

1. Melakukan kajian dan identifikasi terhadap daerah aliran irigasi berdasarkan potensi data yang tersedia ditinjau dari konstruksi sipilnya.

2. Menyiapkan desain studi yang terstruktur dan sistematik sebagai kerangka acuan mengumpulan data dan informasi di lapangan.

3. Melakukan site investigation berupa pengambilan data potensi sumber daya air, data demografi dan kewilayahan, data sosial ekonomi dan elektrifikasi. 
4. Melakukan croschek pengambilan data dari instansi terkait yang berhubungan dengan debit yang didesain yang telah ada serta data curah hujan yang ada.

Alat dan bahan yang dipakai dalam melakukan pengambilan data ini adalah :
1. Stop wotch
4. Water pas
2. Meteran
5. Tali
3. Pelampung plastic
6. Alat tulis

\section{b. Metode pengukuran}

1. Pengukuran harus dibuat pada tempat dimana poros dari aliran adalah lurus dan bagian melintang dari sungai hampir seragam.

2. Jarak pengaliran pelampung harus lebih dari lebar sungai.

3. Penempatan garis melintang pada bagian atas dan bagian bawah tegak lurus ke poros dari aliran. Jarak aliran (garis aliran atas dan garis aliran bawah) $=\mathrm{L}$.

4. Pengukuran bagian area melintang pada garis melintang atas dan bawah untuk membuat nilai rata-rata dari bagian area melintang dari aliran (A mean).

5. Pengukuran tambahan harus dibuat pada bagian tengah dari dua garis jika bagian melintang dari sungai tidak seragam.

6. Pelampung dilepaskan pada bagian atas dari garis melintang melintang atas ke garis melintang bawah di ukur.

7. Pengukuran harus dibuat beberapa kali pada pada blok yang berbeda, dibagi pada sungai di arah garis melintang.

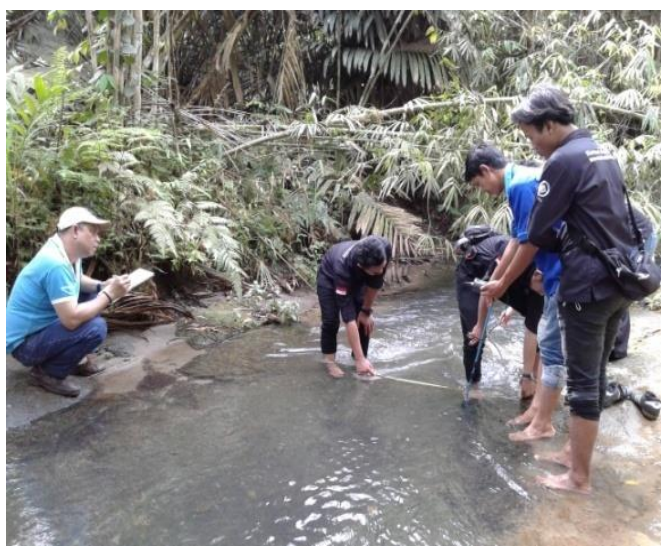

Gambar 3. Pengukuran debit dan laju air sungai sumbul.

\section{c. Pengambilan Data Besaran Elektrikal dan Mekanikal}

Apabila kita akan melakukan pengambilan data berupa besaran elektrikal-mekanikal maka terlebih dahulu melakukan upgrade pembangkit dari $1,1 \mathrm{~kW}$ menjadi $5 \mathrm{~kW}$ sesuai dengan kebutuhan warga Bintang Asih. Adapun peralatan yang dibutuhkan adalah sebagai berikut:
- Turbin

- Sistem transmisi mekanik

- Generator sinkron

- Sistem kontrol beban ELC

- Ballast load air heater.

Kemudian melakukan perancangan generator dengan putaran rendah $(\leq 1000 \mathrm{rpm})$. Putaran rendah akan meringankan pemilihan transmisi kecepatan yang diperlukan. Kapasitas generator sama atau lebih besar dari pada kapasitas yang bisa dibangkitkan turbin. Hal ini sejalan dengan penelitian yang dilakukan dengan kesimpulan bahwa untuk mengurangi kecepatan nominal generator maka dilakukan penambahan jumlah kutub pada rotor, sehingga dihasilkan generator dengan putaran rendah agar dapat di manfaatkan secara langsung pada PLTMH (Rimbawati dan Hutasuhut, 2013)

Untuk mendukung tingkat keberhasilan program maka tim memperdalam kajian pada tahun sebelumnya dengan memodifikasi motor induksi 3 phasa menjadi generator dengan mengubah desain rotor dan untuk mengurangi kecepatan nominal generator maka jumlah kutup pada rotor generator di perbanyak sehingga dapat mengurangi rugi-rugi transmisi pada perlengkapan Power House. Setelah melakukan pengujian terhadap hydroelctric generator 3 phasa diperoleh frekuensi keluaran sistem $49 \mathrm{~Hz}$, pada putaran $\leq 1000 \mathrm{Rpm}$ dengan tegangan Phasa ke Netral sebesar 183,85 Volt dan tegangan Phasa ke Phasa sebesar 320,48 Volt.

\section{d. Pemasangan MCB (Mini Circuit Breaker)}

Program kerja yang terakhir pada tahun pertama adalah pemasangan MCB di setiap rumah warga, hal ini bertujuan untuk membatasi penggunaan daya pada setiap rumah sehingga tidak terjadi pertikaian antar individu. Pada pekerjaan ini Tim memberikan:

- MCB 1 buah setiap rumah

- Lampu hemat energi 4 buah setiap rumah

- Saklar saklar 1 buah setiap rumah

- Stop Kontak 1 buah setiap rumah

\section{HASIL DAN PEMBAHASAN}

\subsection{Sosialisasi Pembangunan PLTMH Kepada Masyarakat}

Pada tahap ini Tim PPDM melakukan sosialisasi terlebih dahulu kepada seluruh warga dusun Bintang Asih guna memberikan pemahaman berkaitan dengan program yang akan dilaksanakan. Pendekatan ini diterapkan guna menyatukan presepsi kepada masyarakat bahwa kehadiran Perguruan Tinggi bukan memberikan materi tetapi memberikan transfer teknologi berupa inovasi PLTMH dalam mendukung program percepatan pembangunan desa 3T (Tertinggal, Terdepan, Terluar) demi terwujudnya masyarakat adil makmur dan sentosa. Selain daripada itu tim juga memberikan penjelasan bahwa akan melakukan program pemberdayaan untuk meningkatkan pendapatan melalui pelatihan pembuatan gula merah yang bersih. Pemberian pemahaman yang akurat akan memudahkan tim dalam melaksanakan program, sebab 
warga akan merasa memiliki dengan semua fasilitas yang diberikan, bergotong royong, bahu membahu demi terlaksananya program serta diharapkan akan melakukan perawatan secara swadaya saat program berakhir. Pada saat sosialisasi program warga juga menyampaikan akan memberikan sumbangsih tempat tinggal dan konsumsi tim selama program berlangsung sebagai bentuk peran serta aktif dalam mensukseskan program.

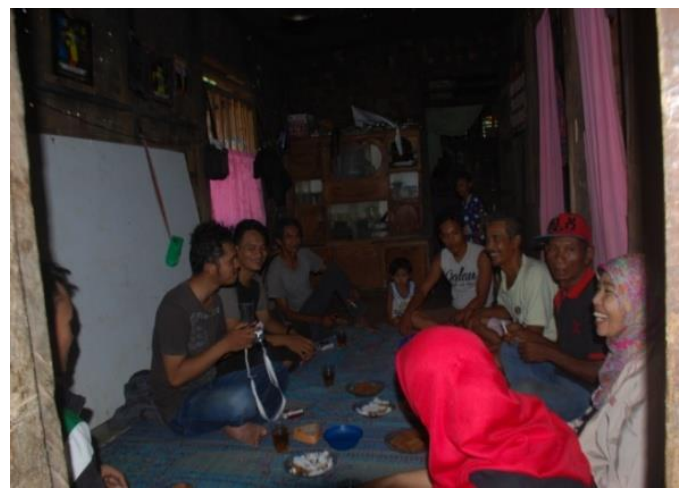

Gambar 4. Sosialisasi program PPDM kepada warga Bintang Asih.

\subsection{Survei Potensi Sumber Daya Air}

Kegiatan ini dilakukan dalam rangka menyiapkan desain studi yang terstruktur dan sistematik sebagai kerangka acuan pengumpulan data dan informasi di lapangan. Melakukan Site Investigation berupa pengambilan data potensi sumber daya air, data demografi dan kewilayahan, data sosial ekonomi dan elektrifikasi dengan model. Sebelum menghitung debit air, maka langkah awal yang perlu dilakukan adalah menghitung kecepatan air dan menghitung penampang basah.

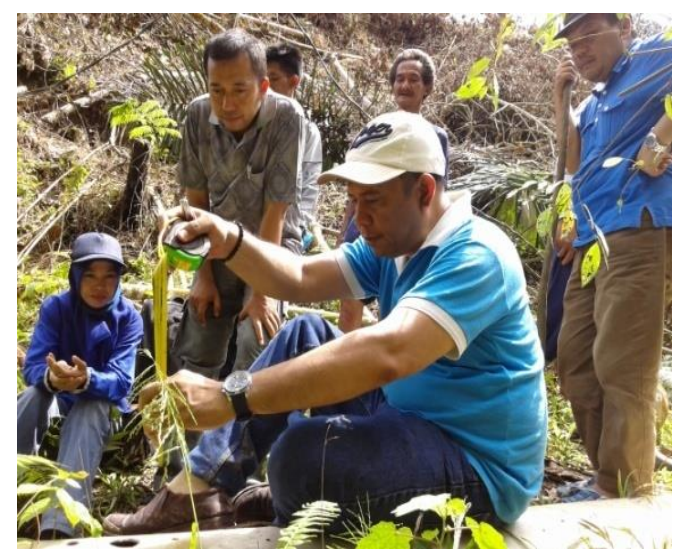

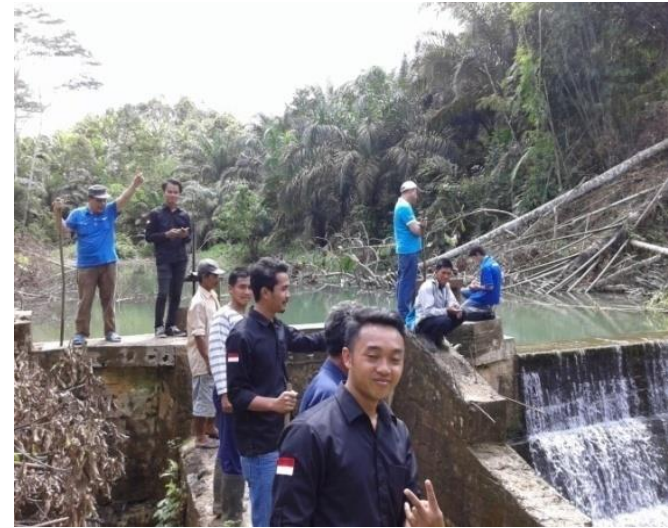

Gambar 5. Pengukuran debit dan laju air sungai dan kondisi bending.

Dari hasil pengukuran diperoleh data-data potensi sebagai berikut: debit air sungai sebesar $341 \mathrm{~m}^{3} / \mathrm{s}^{2}$, tinggi jatuh air yang akan dimanfaatkan adalah $2 \mathrm{~m}$ hingga $4 \mathrm{~m}$.

\subsection{Pengambilan Data Besaran Elektrikal dan Mekanikal}

Pembangkit Listrik Tenaga Mikrohidro (PLTMH) pada prinsipnya memanfaatkan beda ketinggian dan jumlah debit air per detik yang ada pada aliran air saluran irigasi, sungai atau air terjun. Aliran air ini akan memutar poros turbin sehingga menghasilkan energi mekanik. Energi ini selanjutnya menggerakkan generator dan menghasilkan listrik.

Berdasarkan hasil rancangan yang dilakukan maka tim melakukan modifikasi untuk mendapatkan daya keluaran seperti yang diinginkan. Selanjutnya upgrade PLTMH pun dilakukan dengan mengimplementasikan semua peralatan yang sudah dirancang sebelumnya dari pengukuran data lapangan. Tim, mahasiswa dan warga masyarakat bergotong royong dalam membangun pembangkit, menempuh medan yang sangat sulit. Namun semangat tim yang solit bersama warga membuat kesulitan tersebut dapat diatasi dengan baik, serta seluruh program dapat terlaksana sesuai jadual yang telah direncakan oleh tim.

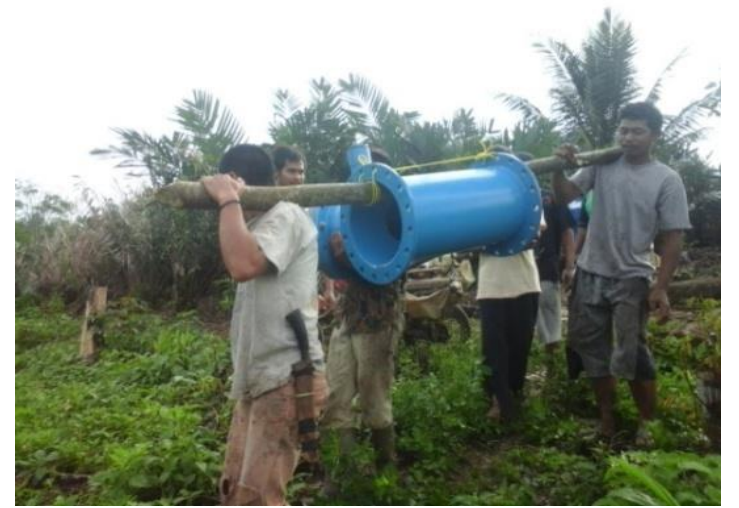

Gambar 6. Warga bergotong royong dengan tim dalam mobilisasi material. 


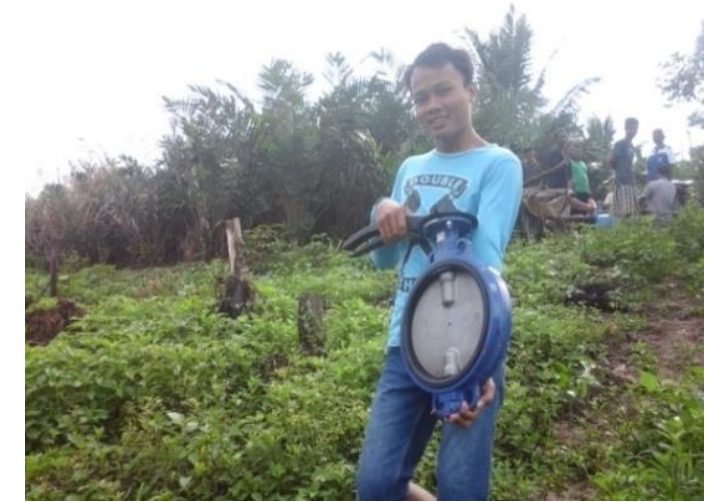

Gambar 7. Salah satu mahasiswa tim PPDM.

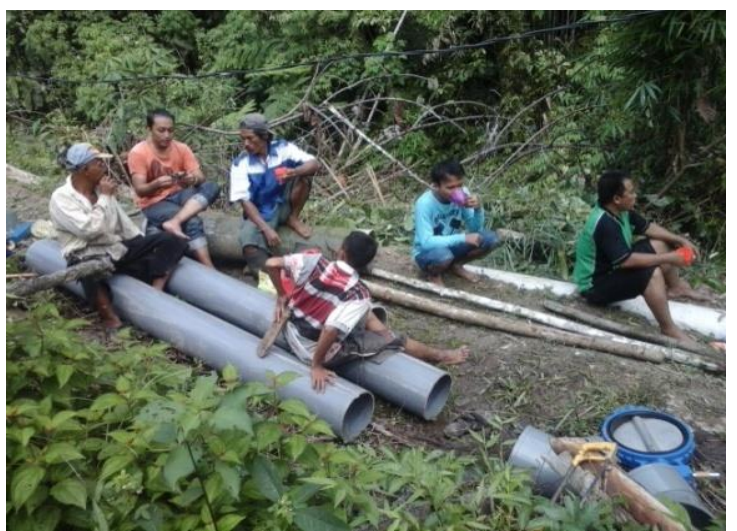

Gambar 8. Warga sedang istirahat saat mobilisasi material.

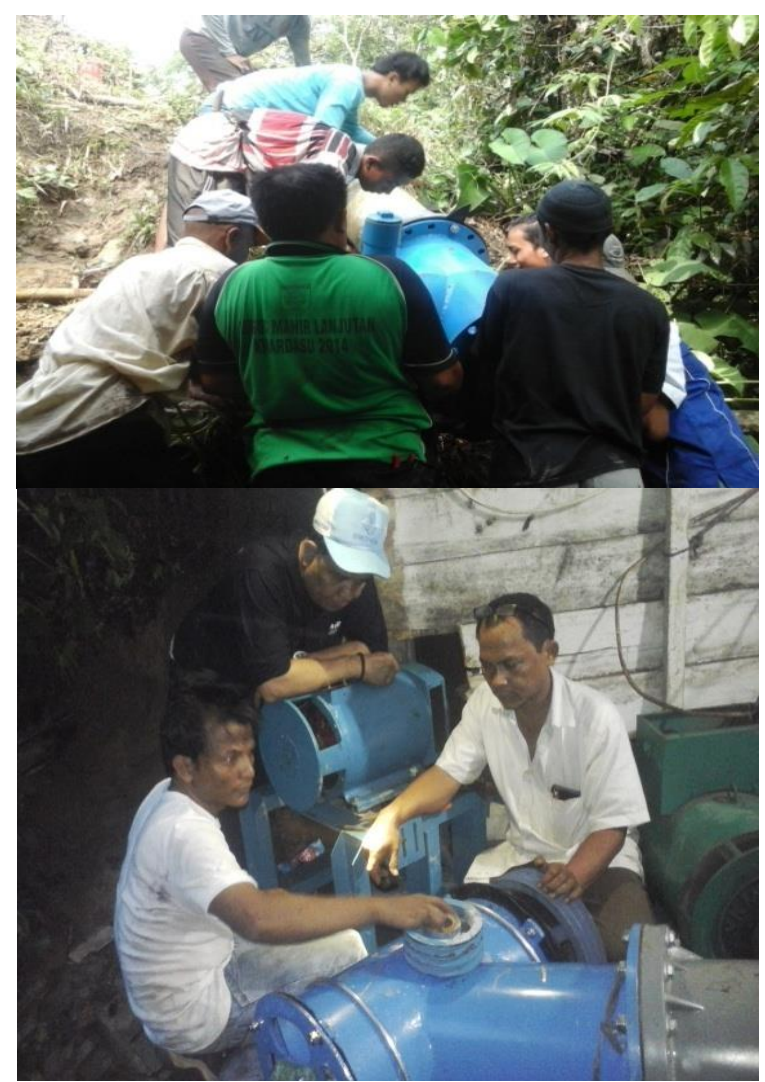

Gambar 9. Tim, tenaga ahli dan warga melakukan modifikasi PLTMH.
Generator adalah suatu alat yang dapat mengubah tenaga mekanik menjadi energi listrik melalui proses induksi elektromagnetik. Tenaga mekanik bisa berasal dari panas, air, uap, dan lain sebagainya. Energi listrik yang dihasilkan oleh generator bisa berupa Listrik AC (listrik bolak-balik). Walau generator dan motor punya banyak kesamaan, tetapi motor adalah alat yang mengubah energi listrik menjadi energi mekanik. Generator mendorong muatan listrik untuk bergerak melalui sebuah sirkuit listrik eksternal, tetapi generator tidak menciptakan listrik yang sudah ada di dalam kabel lilitannya. Hal ini bisa dianalogikan dengan sebuah pompa air, yang menciptakan aliran air tetapi tidak menciptakan air di dalamnya

Setelah melakukan pemasangan seluruh peralatan pembangkitan maka dilakukan uji coba peralatan PLTMH seperti pada gambar 10.

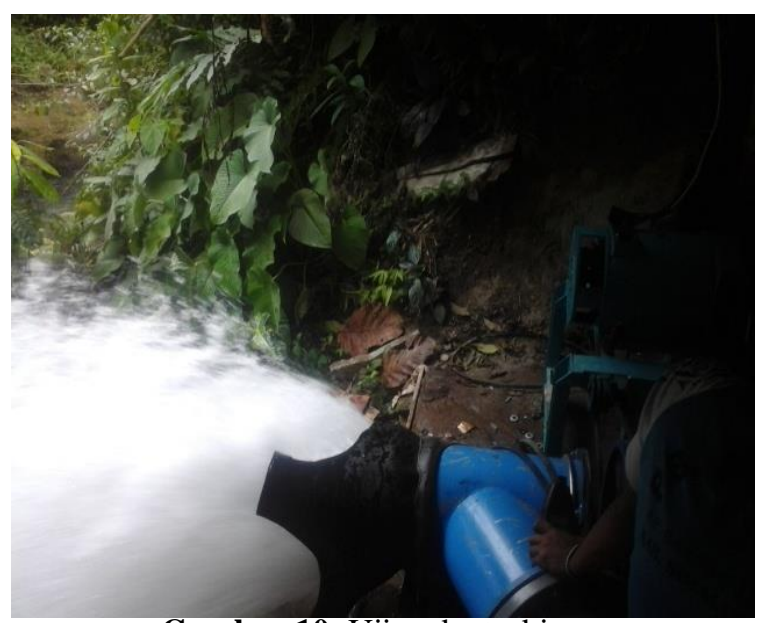

Gambar 10. Uji coba turbin.

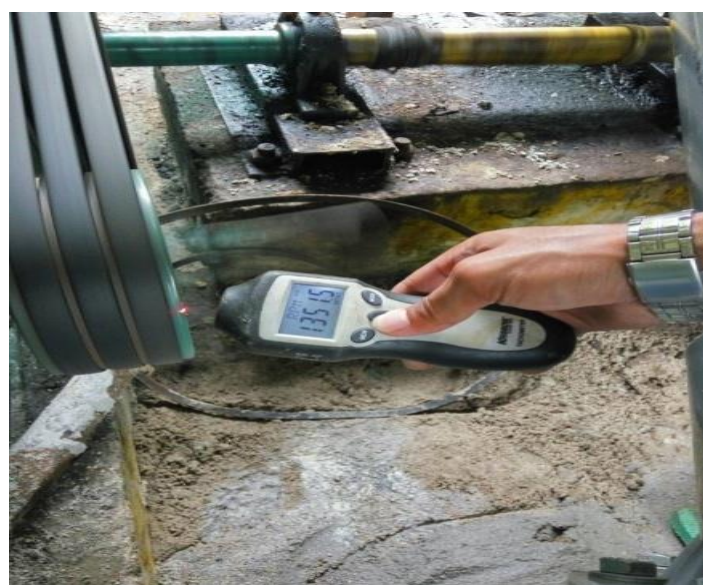

Gambar 11. Ketua tim dan mahasiswa melakukan pengukuran putaran generator.

Setelah dilakukan modifikasi maka dihasilkan sebuah PLTMH yang menggunakan turbin dengan besaran elektrik sebagai berikut :

(1) Pengukuran arus beban (4,50 A)

(2) Pengukuran tegangan (148 V)

(3) Pengukuran putaran /frekuensi $(49.2 \mathrm{~Hz})$

(4) Pengukuran daya yang dikeluarkan $(5,1 \mathrm{~kW})$ 
(5) Pengukuran daya yang dikeluarkan / perjam $(\mathrm{kWH})$

Kapasitas generator yang sama atau lebih besar dari kapasitas yang bisa dibangkitkan turbin akan berpengaruh pada daya yang dibangkitkan dan kwalitas tegangan.

\subsection{Perancangan Sistem Kontrol menggunakan Electronic Load Control (ELC)}

Pekerjaan yang sangat berat pun selesai dilakukan dalam meng-upgrade PLTMH Bintang Asih, hal tersebut diakibatkan sulitnya medan yang harus ditempuh oleh tim dan juga warga, karena jarak pembangkit yang cukup jauh \pm 700 $\mathrm{m}$ dari pusat beban (rumah warga). Selanjutnya Tim bersama Tenaga Ahli melakukan pemasangan Electonic Load Control (ELC). Ini dimaksdukan untuk mempermudah sistem pengontrolan pembangkitan dan juga beban yang ada. Dalam pelaksaan program ini, sistem kontrol beban yang digunakan adalah berbasis Programmable Logic Controller (PLC), dan sistem pengontrolan tegangan berbasis modul deep sea elektronik 3110. Penggunaan sistem pengontrolan otomatis dilakukan dengan pertimbangan untuk memudahkan tim dan warga dalam memantau kondisi sistem tanpa harus turun ke lokasi pembangkit, hal ini mengingat jarak yang cukup jauh serta jalan yang cukup ekstrim menuju ke lokasi pembangkit. Seluruh sistem kontrol tersebut dapat dikendalikan dari control utama yang dipasang pada pemukiman warga. Apabila terjadi permasalahan pada pembangkitan maupun beban maka sistem kontrol akan memberikan sinyal pada bazer untuk menghidupkan sirine.

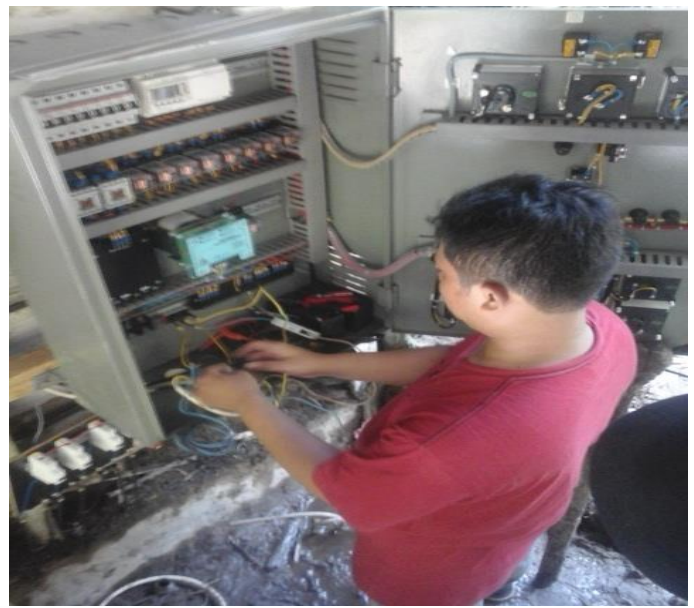

Gambar 12. Perakitan modul deep sea elektronik 3110 .

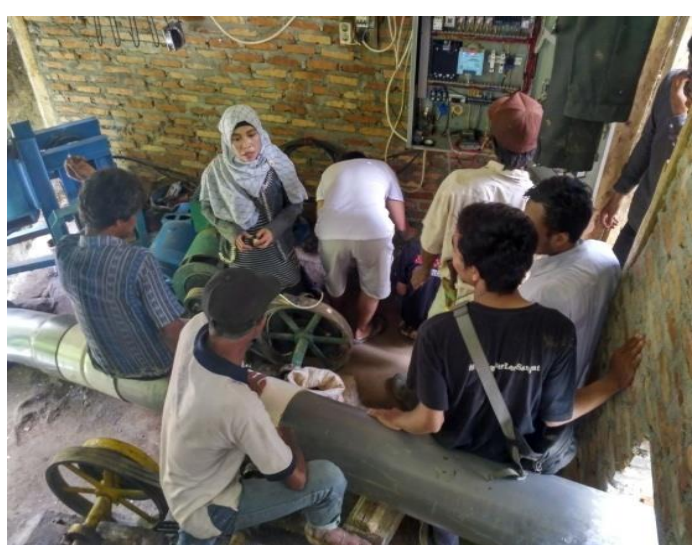

Gambar 13. Perakitan sistem kontrol beban.

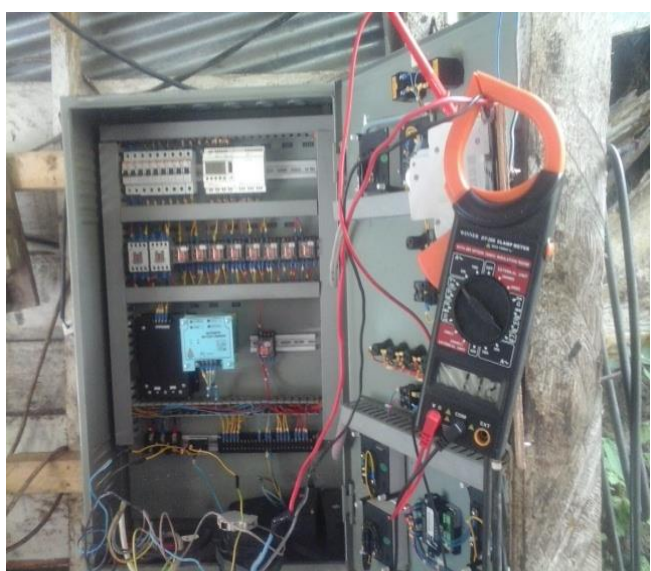

Gambar 14. Uji Coba Sistem Pengontrolan Beban.

\subsection{Pemasangan MCB (Mini Circuit Breaker) dan Saklar}

Tahapan terakhir yang dilakukan dalam pengabdian ini adalah pemasangan MCB, saklar dan stop kontak di rumah warga, hal ini bertujuan untuk membatasi penggunaan daya pada tiap rumah sehingga tidak terjadi perdebatan dengan sesama warga. Selanjutnya setiap rumah diberi lampu sebanyak 4 buah. Pada kegiatan ini Tim dan warga berkolaborasi dalam pemasangan instalasi listrik, sekaligus memberikan pendampingan agar apabila terjadi permasalan pada jaringan mereka dapat mengatasi sendiri. Saat kegiatan ini berlangsung cukup banyak permasalahan akibat rumah warga yang pada umumnya berdinding tepas, sangat menyulitkan tim dalam melakukan pemasangan peralatan. Ditambah lagi dengan keterbatasan peralatan yang ada di lokasi. Pengalaman lapangan yang sangat berkesan adalah saat kekurangan 1 matrial saja misalnya: isolasi, maka kita harus pergi ke kota dengan jarak tempuh 2 jam. Pengabdian yang cukup menantang, walau demikian kami yakin bahwa apa yang kami lakukan sangat bermanfaat bagi masyarakat desa tertinggal. 


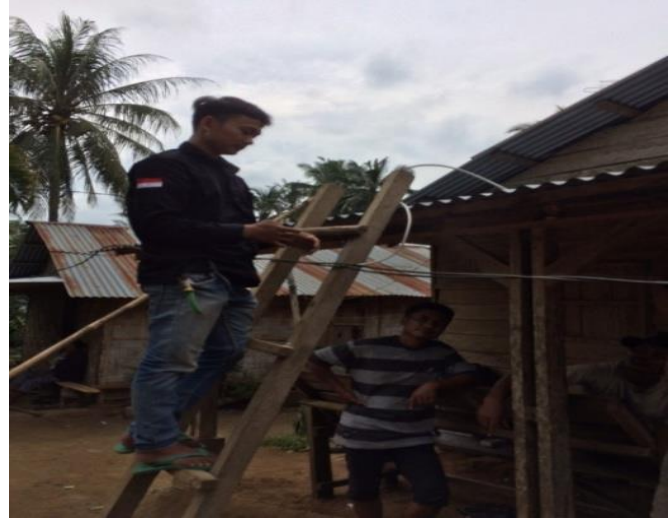

Gambar 15. Pemasangan mini circuit breaker.

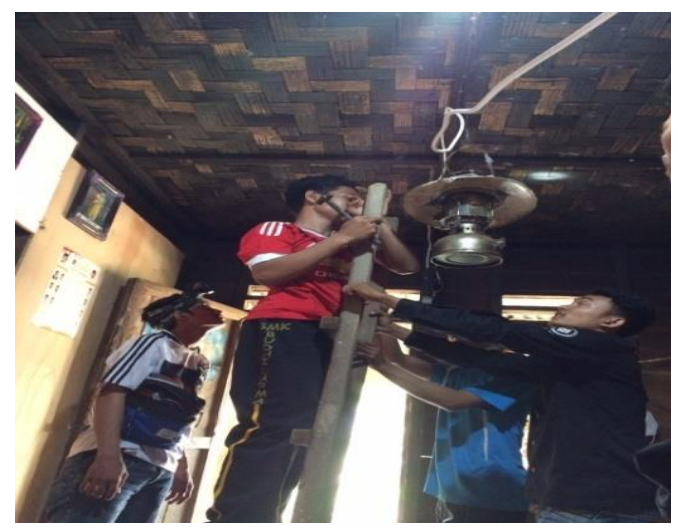

Gambar 16. Pemasangan saklar di rumah warga.

\subsection{Program Pemberdayaan Masyarakat}

Program pemberdayaan masyarakat yang diusung oleh tim adalah: pembuatan gula merah dengan bahan dasar nira aren. Program ini dijadikan sebagai gerakan ekonomi pedesaan berdasarkan kearifan lokal masyarakat setempat, sehingga dapat dijadikan sebagai pendapatan tambahan warga Bintang Asih. Kegiatan tersebut biasanya dilakukan warga pada malam hari untuk mengisi kekosongan waktu menjelang tidur. Adapun nira diperoleh dari hutan sepanjamg sungai yang disadap setelah mereka istirahat dari pekerjaan buruh tani pada perkebunan karet dan sawit yang mereka kerjakan setiap hari. Setelah program berlangsung setiap KK dalam 1 pekan dapat menghasilkan gula aren rata-rata $15 \mathrm{~kg}$ dengan harga jual di pasar tradisonal sebesar Rp 18.000/kg. Berdasarkan keterangan warga adanya fasilitas penerangan yang sangat memadai dapat meningkatkan ekonomi dan kebutuhan informasi saat ini dapat terpenuhi, khususnya dapat mendapat informasi dari media televisi.

\subsection{Perbandingan Sebelum dan Sesudah pelaksanaan Program}

Setelah berakhirnya program pengabdian maka dilakukan analisa lapangan tentang perbandingan sebelum dan sesudah dilakukannya kegiatan. Dari hasil analisis diperoleh terjadi perbedaan yang sangat signifikan antara sebelum dan sesudah dilakukan program tersebut. Warga Bintang Asih saat ini telah menikmati fasilitas penerangan yang cukup memadai sehingga kegiatan ekonomi lebih berputar dan kebutuhan informasi baik pendidikan dan media dapat diakses dengan baik. Anak- anak usia sekolah saat ini sudah dapat belajar dengan baik pada malam hari serta dapat mengakses informasi dari media elektronik. Untuk lebih jelas dapat dilihat pada gambar 17- 20 berikut ini.
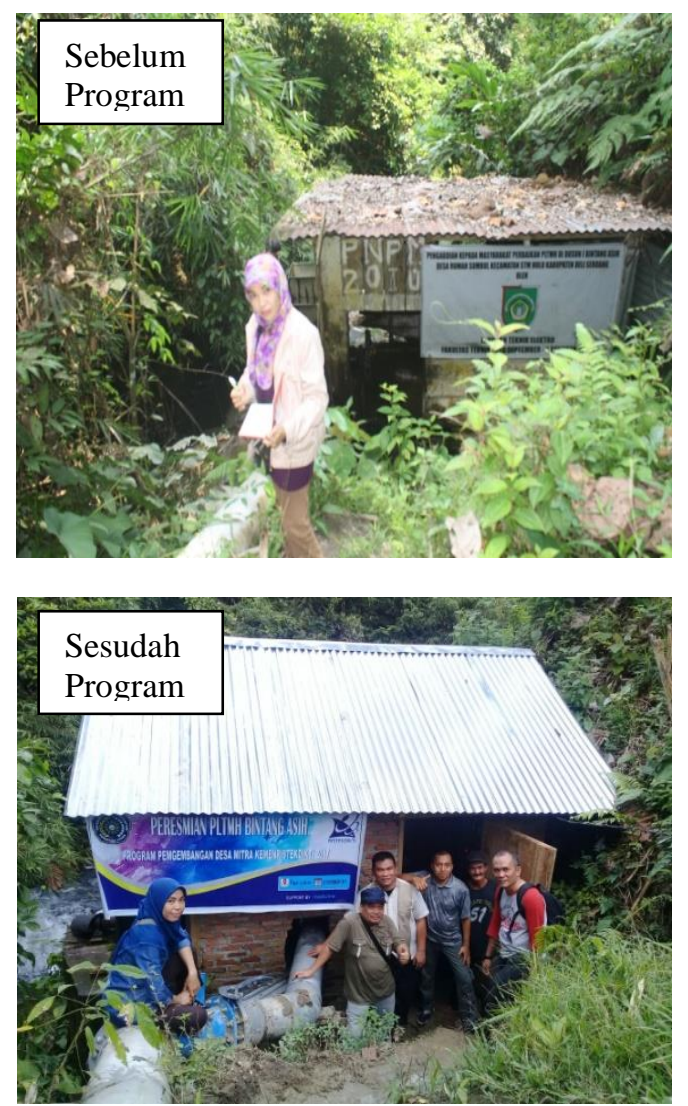

Gambar 17. Kondisi Power House sebelum dan sesudah program dilakukan.
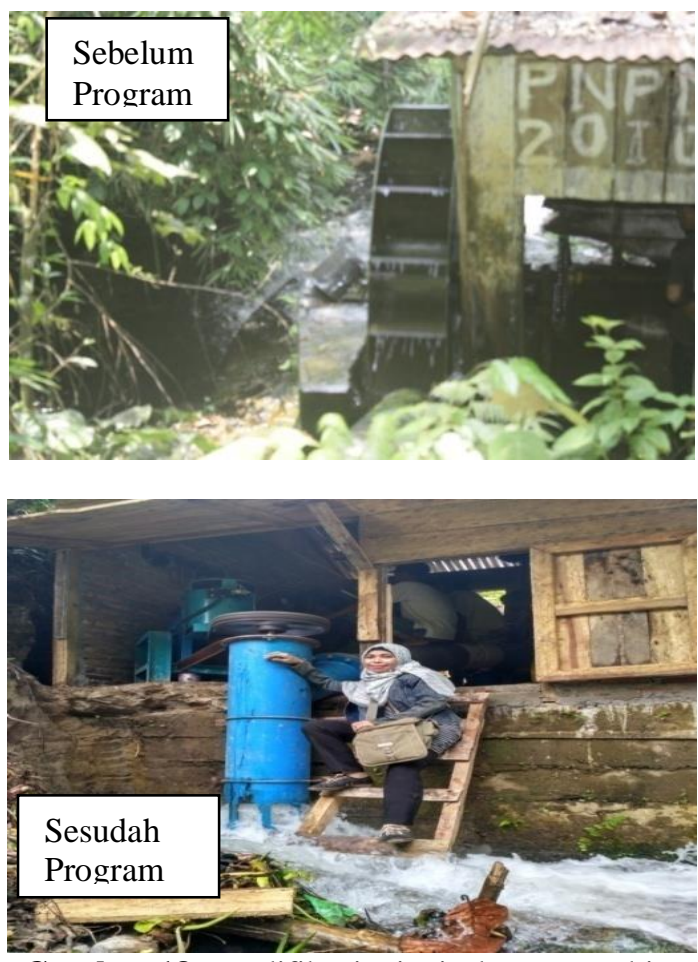

Gambar 18. Modifikasi Kincir dengan Turbin. 

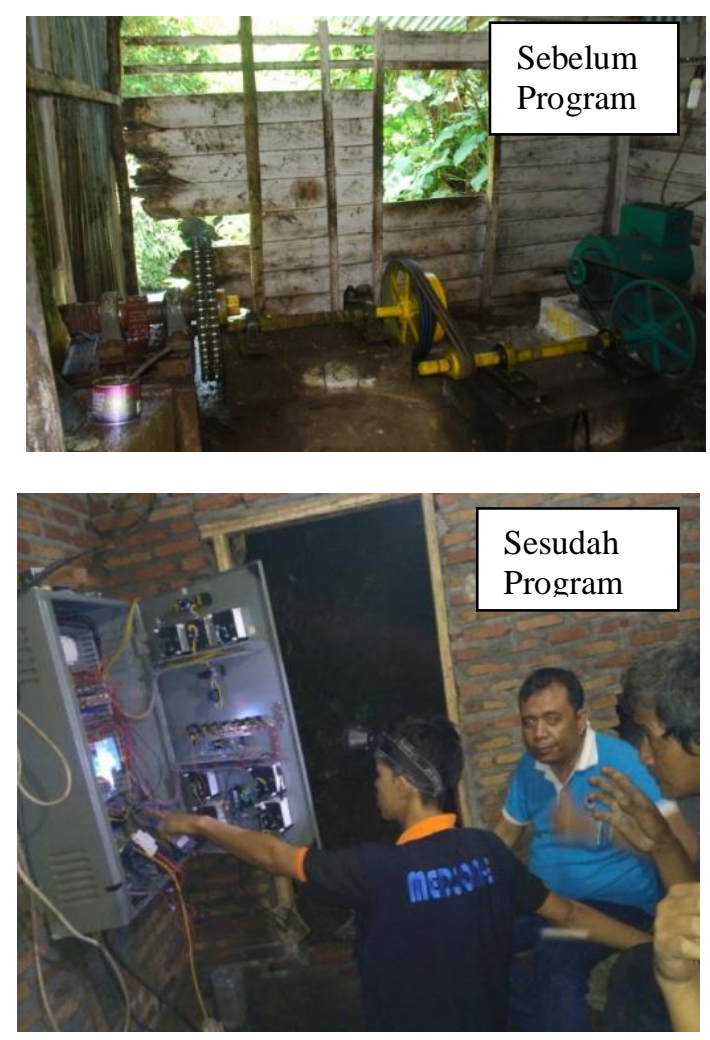

Gambar 19. Sistem kontol beban dan pembangkitan.

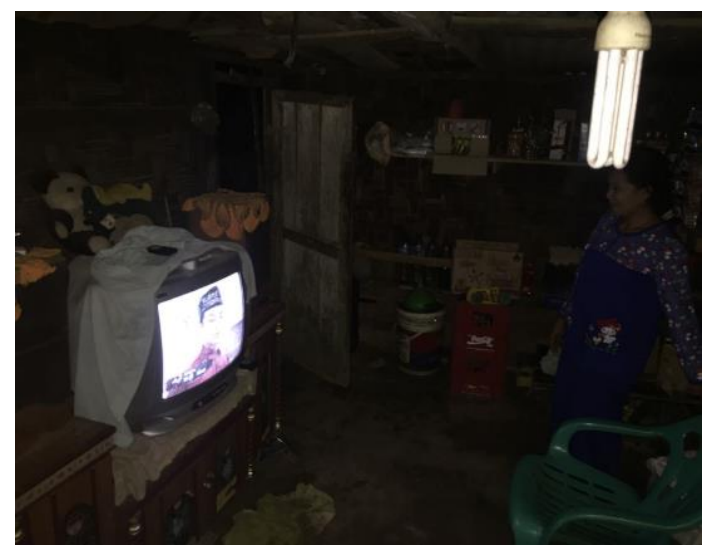

Gambar 20. Hasil Akhir Pengabdian Masyarakat tim PPDM UMSU tahun 2017.

\section{KESIMPULAN}

Dengan berakhirnya program pengabdian masyarakat ini dapat disimpulka bahwa:

1. Program telah terlaksana dengan sangat baik berupa peningkatan kapasitas PLTMH dengan mengubah kincir menjadi turbin dimana pembangkitan memiliki kapasitas $5 \mathrm{KW}$ serta memasang seluruh peralatan pembangkitan, sistem distribusi, pemasangan Electronic Load Control (ELC), pemasangan Mini Circuit Breaker (MCB), saklar dan stop kontak di setiap rumah warga.

2. Sosialisasi manajemen PLTMH yang dilakukan oleh tim, dapat memberikan pemahaman kepada masyarakat terhadapa transfer teknologi yang diberikan juga menumbuhkan rasa memiliki terhadap teknologi yang di tinggalkan.
3. Program pemberdayaan dalam hal pendampingan pembuatan gula merah berbahan dasar nira aren saat program berakhir sudah mampu diproduksi warga dengan sangat baik dengan total produksi 60 $\mathrm{kg} / \mathrm{bulan}$.

\section{UCAPAN TERIMA KASIH}

Terima kasih disampaikan kepada Direktur Riset Pengabdian Masyarakat KemenristekDikti yang telah memberikan dukungan dana dalam pelaksanaan pengabdian ini, semoga bermanfaat untuk kesejahteraan rakyat.

\section{DAFTAR PUSTAKA}

Ion, Catalin Petrea, Ioan Serban, and Corneliu Marinescu. 2006. "A Single-Phase Dump Load for Stand-Alone Generating Units with Induction Generator," no. 30: 233-36.

Rimbawati; Abdul Azis Hutasuhut. 2013. "Rancang Bangun Hydroelectric Generator Satu Phasa Menggunakan Motor Induksi Sisa Pakai Untuk PLTMH.” In , 222-34.

Rimbawati; Abdul Azis Hutasuhut; Muharnif. 2015. "Rancang Bangun Hydroelectric Generator Tiga Phasa Menggunakan Motor Induksi Sisa Pakai Untuk PLTMH.” In , 380-86. 